\title{
Fabrication of Biochar from Organic Wastes and its Effect on Wheat Growth and Soil Microflora
}

\author{
Sadia Aziz', Laiba Yaseen ${ }^{1}$, Asif Jamal ${ }^{1}$, Uzma Farooq ${ }^{2}$, Zahid Qureshi', \\ Isfahan Tauseef ${ }^{4}$, Syed Kashif Haleem ${ }^{4}$, Muhammad Ishtiaq Ali ${ }^{1 *}$ \\ ${ }^{1}$ Department of Microbiology, Quaid-i-Azam University, Islamabad, Pakistan \\ ${ }^{2}$ Department of Plant Sciences, Quaid-i-Azam University, Islamabad, Pakistan \\ ${ }^{3}$ Government College University, La-hore, Pakistan \\ ${ }^{4}$ Department of Microbiology, Hazara University Pakistan
}

Received: 2 October 2018

Accepted: 18 November 2018

\begin{abstract}
In modern agricultural practices, applying biochar to improve soil fertility, plant growth and agricultural output is gaining a great deal of attention. Our current study highlights the preparation of biochar from fruit and vegetable waste and nutshell waste and its application as biofertilizer. The prepared biochar from both resources was characterized via Fourier transform infrared spectroscopy (FTIR), x-ray diffraction (XRD), and scanning electron microscopy (SEM). Both types of biochar and their mixture were tested in a short-term lab-scale pot experiment at two different rates $(0.5 \%, 1 \%$ $\mathrm{w} / \mathrm{w})$ in order to evaluate their relative efficacy in soil fertility and wheat yield. Soil parameters like $\mathrm{pH}$, electrical conductivity, total carbon, total nitrogen, phosphorous, and potassium were analysed before and after plant growth by standard procedures. At the end of the experiment plant growth and dry biomass was calculated. Analytical characterization of biochar depicts its crystalline nature with the presence of carbon nanotubes and circular pores. Wheat growth effects varied with biochar type, but overall positive growth results were observed for both biochar and their mixture. Results proved that wheat growth and biomass production was highest with maximum concentration of biochar mixture, while the highest microbial count was observed with $1 \%$ nutshell biochar. Promising wheat growth and a shift in relative abundance of the microbial community could have resulted from improvement in soil parameters such as highest soil EC of $190 \mathrm{us} / \mathrm{cm}$. Phosphorous and potassium concentrations of $12 \mathrm{mg} / \mathrm{kg}$ and $210 \mathrm{mg} / \mathrm{kg}$ were observed at $1 \%$ mixture of biochar. In $1 \%$ fruit and vegetable waste biochar highest TC of $0.459 \%$ was observed in soil. Furthermore, the highest TN of $0.0325 \%$ was examined at $0.5 \%$ mixture of biochar. Our results conclude that the biochar amendment in soil at optimum level improves soil physiochemical properties and enhances soil microflora, which in turn cast a positive influence on soil productivity and crop growth.
\end{abstract}

Keywords: biochar, fruit and vegetable waste, nutshell waste, wheat, soil microbiology

*e-mail: ishimrl@qau.edu.pk 


\section{Introduction}

Increasing sensitivity towards environmental protection and sustainability has gathered significant interest in natural products and processes. In particular, the emerging scientifically verified data supports the fact that biochar can improve soil productivity, stimulates plant growth and improves environmental quality by countering synthetic agrochemical and pollutant effects. In agriculture-based countries like Pakistan, most of the population has been associated with agribusiness. According to reports, around $60 \%$ of the population relies on agriculture, with a $21 \%$ contribution toward gross domestic product (GDP) [1]. The agriculture sector of Pakistan has been facing serious issues regarding soil fertility. The principle reasons for continual decrease in soil quality include loss of top soil layers, nutrient mining, physical degradation, poor soil management and pollution [2-3].

To reclaim soil, various strategies have been adopted like the use of chemical fertilizers, but they also have disadvantages. One of the biggest issues with chemical fertilizers is that they are not cost-effective and cause land pollution and groundwater contamination. The agriculture sector need such systems that are ecofriendly and help promote and maintain biological processes, like the use of organic fertilizer, mixed cropping, animal manure, and green manure. The application of animal fertilizer and manure maintains the level of natural matter in soil. Synthetic compost can be expected to rapidly supply the soil with required nutrients [4].

Along with compost, biochar is an emerging tool in this respect as history has witnessed increased fertility of terra peta soils due to biochar. Biochar is commonly derived with various feedstock materials and is created from the thermal breakdown of natural material under a restricted supply of oxygen. Production of biochar under various pyrolysis conditions effects soil physiochemical properties, which may then have a quick influence on plant development [5]. Biochar amendment into soils is of essential significance in deciding the ecological advantages of biochar as it decides to what extent carbon in biochar will be retained in soil, thus enhancing soil quality [6].

Biochar addition alters the microbial community present in soil as well as its composition [7-8]. The existence of pores in biochar gives a reasonable habitat to soil microorganisms by shielding them and by fulfilling their carbon and mineral requirements [9]. These progressions influence microbial structures and nutrient cycling that in some way influences plant development [6].

The application of biochar for plant growth, soil physiochemical properties and the microbial community has driven a significant impact on agriculture practices. Biochar has been considered an important alternative fertilizer as it improves agriculture outputs by managing the effect of environmental changes and on the other side decreases greenhouse gas emissions [10]. In the present era, strategies are being employed that can produce cost-effective biochar. However, there is a need to improve understanding regarding biochar influence on the agriculture properties of soil - in particular its effect on plant growth and soil microbiota. The present study was attempted to produce, characterize and apply biochar in agricultural soil in order to understand its effect on wheat growth and soil microbiota.

\section{Materials and Methods}

\section{Soil Collection}

Soil collection was done at a depth of $0-20 \mathrm{~cm}$ from the garden area of Quaid I Azam University in Islamabad, Pakistan. Debris, grass, stones, and unwanted particles were removed from the soil.

\section{Biochar Production}

Fruit and vegetable waste like mango, apple, pomegranate, orange peels and nut shell waste (peanut, almond, and walnut shells) were collected from university cafeterias and food huts. The samples were air dried and transferred to a muffle furnace set at $550^{\circ} \mathrm{C}$ for 2 hours.

\section{Pot Experiment}

To investigate biochar impact on wheat growth, treatment was conducted in plastic pots. Three sets of pots (set 1, set 2, and set 3) were prepared. In the first set fruit and vegetable waste biochar was added, in the second set nut shell biochar was added, in the third set a mixture of both types of biochar (nut shell + fruit and vegetable waste) was added. Biochar addition in pots was with two varying rates $(0.5 \%$ and $1 \%)$ while the control was with $0 \%$ biochar. 3-4 seeds of wheat were sown in each pot (Table 1).

\section{Characterization of Biochar}

$\mathrm{pH}$ was determined in 1:5 biochar-to-water ratio as described by Pandian et al., 2016 [11]. Surface morphology of biochar was observed using a JSM $5910 \mathrm{lv}$ thermionic scanning electron microscope (Jeol SEM, Japan) to establish macro-pore shape [12]. $\mathrm{X}$-ray diffraction was performed on the biochar using a Shimadzou XRD-6000 Diffractometer. $3 \mathrm{~g}$ of each char were granulated for powder diffraction using $\mathrm{Cu} \mathrm{K \alpha} 0.154 \mathrm{~nm}$ radiation $(40 \mathrm{kV}, 30 \mathrm{~mA})$ from $5^{\circ}$ to $80^{\circ}(2 \theta)$ with scan rate of $8 \% \mathrm{~min}$ [13]. Samples were analysed by FTIR spectroscopy to check the different functional groups of biochar. A 5-mg powdered sample of biochar was analysed by a Tensor 27 (Bruker) FTIR spectrophotometer. An absorbance spectrum $(600-4000 \mathrm{~cm}-1)$ was collected with $4 \mathrm{~cm}^{-1}$ resolution [13]. 
Table 1. Treatment plan for the experiment.

\begin{tabular}{|c|c|c|c|}
\hline Crops & Substrate & Soil samples & Sets \\
\hline Wheat & Fruit and vegetable biochar & $\begin{array}{l}\text { S, S0, S0.5\%, S1\% } \\
\text { S= Soil at first day }\end{array}$ & Set 1 \\
\hline Wheat & Nut shell biochar & S, S0, S0.5\%, S1\% & Set 2 \\
\hline Wheat & Nut shell + Fruit and vegetable waste biochar & S, S0, S0.5\%, S1\% & Set 3 \\
\hline
\end{tabular}

\section{Physicochemical Characterization of Soil}

Physicochemical characterization of soil was performed before sowing and after harvesting. Soil was mixed thoroughly in water (1 g soil in $2 \mathrm{ml}$ water). Mixture was allowed to settle down for 30 minutes. Soil $\mathrm{pH}$ and Electrical conductivity was measured. Chemical analysis of soil samples for C, N, P, and K was undertaken at the Soil and Water Testing Laboratory for Research, Rawalpindi by standard soil testing methods [14].

\section{Biochar Effect on Plant Growth and Soil Microflora}

To check the effect of biochar on plant growth, plant morphological parameters including plant height and weight were measured. Plant height was calculated starting from stem base to the tip of the tallest leaf, and their dry biomass was calculated [15].

For microbial analysis soil samples were taken from rhizosphere of plants grown in pots. Serial dilutions of soil samples were prepared at up to $10^{-7}$ concentrations. These dilutions were spread on nutrient agar plates which were incubated at $37^{\circ} \mathrm{C}$ for $24 \mathrm{hrs}$. Growth on plates was enumerated by colony counter and CFU was calculated by applying formula

$\mathrm{CFU} / \mathrm{g}=$ colony number $\times$ dilution factor/inoculum size

\section{Results and Discussion}

\section{Characterization of Biochar}

$$
p H
$$

The $\mathrm{pH}$ recorded for fruit and vegetable waste biochar and nutshell biochar was 8.8 and 9.4 respectively. Biochar produced in this study were alkaline, as high $\mathrm{pH}$ is commonly observed for thermally produced biochar [16].

\section{SEM Analysis}

The SEM analysis of the nut shell biochar depicted a porous structure with cracks on the surface of biochar particles (Fig. 1a). The SEM images of fruit and vegetable waste biochar showed discontinuous elliptical and circular pores $10-50 \mu \mathrm{m}$ in diameter spaced between a)

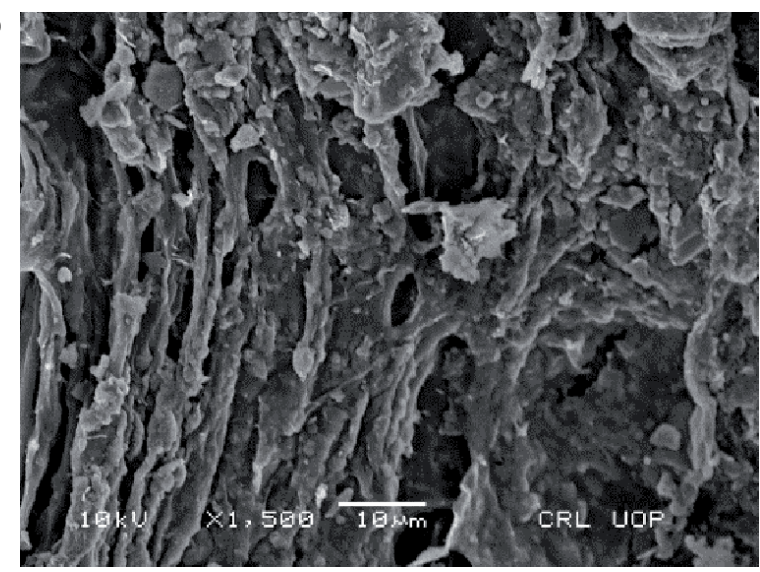

b)

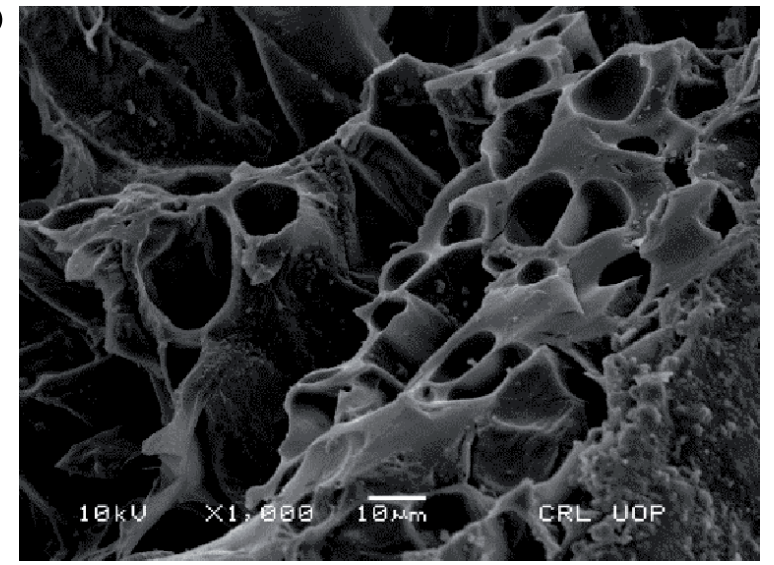

Fig. 1. SEM micrographs of a) nutshell biochar, b) fruit and vegetable waste biochar.

longitudinal sheets of pyrolyzed structure (Fig. 1b). Furthermore, microstructure of both samples of biochar was tightly compact and packed with characteristic macro pores prominent on the surface, suggesting that both biochar samples had a porous structure quite similar to that observed in previous studies [17].

\section{XRD Analysis}

XRD profiles of fruit and vegetable waste biochar and nutshell biochar are shown in Fig. 2(a-b). Characteristic sharp peaks in fruit and vegetable waste biochar and nutshell biochar represent their crystalline nature and changes in the structure of the biomass by pyrolysis. Thermal decomposition of fruit and vegetable waste biomass caused structural changes, converting 

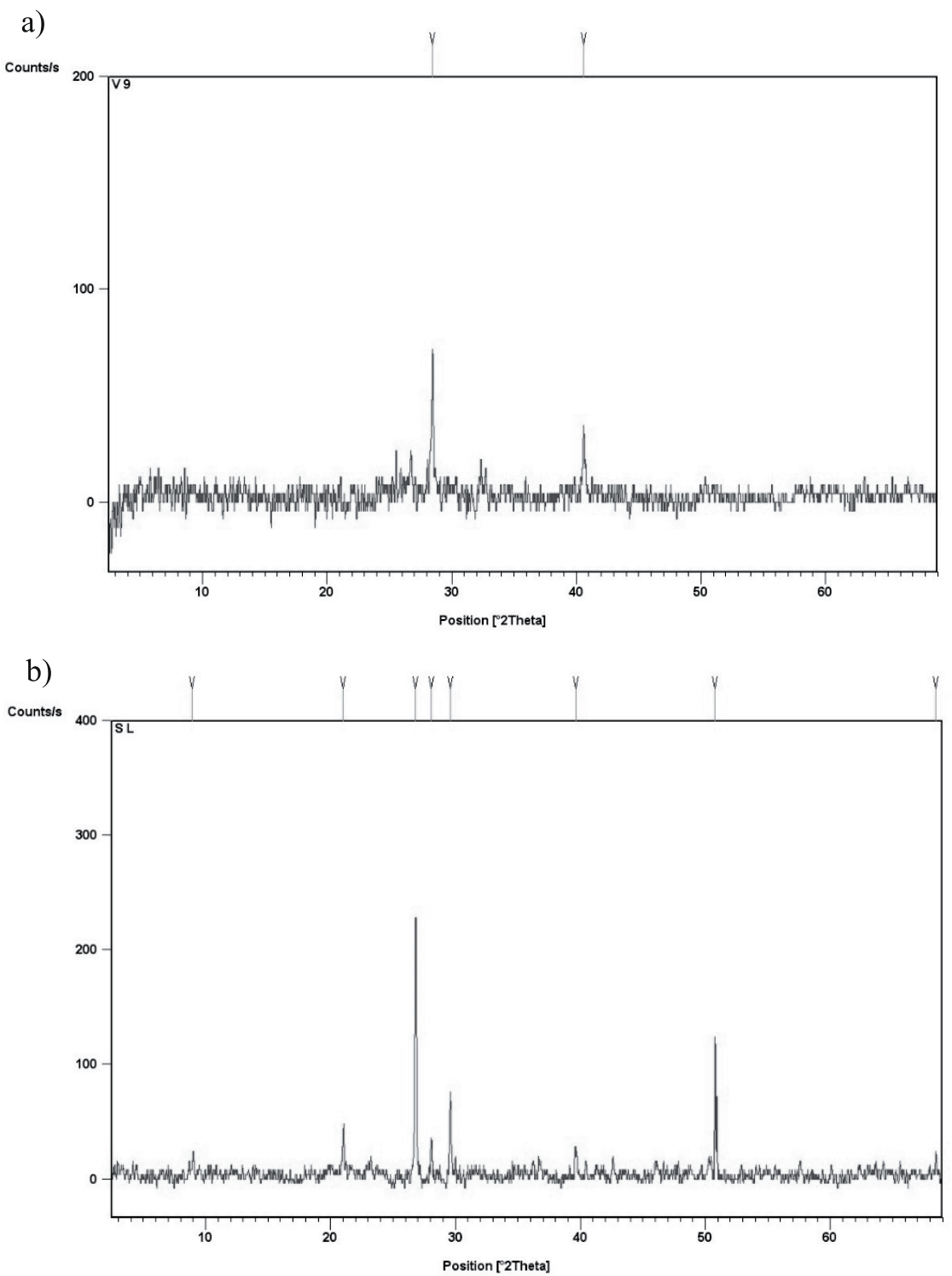

Fig. 2. a) XRD pattern of fruit and vegetable waste biochar; b) XRD pattern of nutshell biochar.

it into graphitic and crystalline form with peak at $28.5^{\circ}$, representing a presence of carbon nanotubes and quartz at $42.5^{\circ}$. The XRD pattern for nutshell biochar also showed peak at $26.8^{\circ}$, representing carbon nanotubes, chaoite peaks at $29.5^{\circ}$ and $39.5^{\circ}$, silicate minerals at $28^{\circ}$, and magnesite at $21.02^{\circ}$ [13-18].

\section{Chemical Analysis of Fruit and Vegetable Waste Biochar by FTIR}

Peaks at 3276.03 and $3010.16 \mathrm{~cm}^{-1}$ region confirm the presence of oxygen-containing $\mathrm{H}$-bonded $\mathrm{O}-\mathrm{H}$ functional groups from alcohols, phenols, and organic acids; 2925.04, 2854.26 and $241.98 \mathrm{~cm}^{-1}$ for stretch of alkyl $\mathrm{C}-\mathrm{H}$ chains; aromatic and olefinic $\mathrm{C}=\mathrm{C}$ vibrations, $\mathrm{C}=\mathrm{O}$ in amide (I), ketone, and quinone groups at 1861.51 and 1707.99 and $\mathrm{cm}^{-1} ; 1577.35,1475.56 \mathrm{~cm}^{-1}$ for carboxylic acid groups; O-H stretch for phenolic compounds at $1280.2,1224.23 \mathrm{~cm}^{-1}$; bands at 1119.52 , 1046,66 and $880.07,829.30,759.99,732.47,646.67$ and $625.48 \mathrm{~cm}^{-1}$ of chlorinated aromatics in biochar. These finding on FTIR seem quite similar to those observed by Jindo et al. [19], indicating an increase in the degree of carbonization that was accelerated due to high

Table 2. Physicochemical analysis of soil samples before any amendment.

\begin{tabular}{|c|c|c|c|c|c|c|}
\hline Soil physiochemical parameters & $\mathrm{pH}$ & $\begin{array}{c}\mathrm{EC} \\
\mathrm{us} / \mathrm{cm}\end{array}$ & $\mathrm{TC} \%$ & $\mathrm{TN} \%$ & $\mathrm{P} \mathrm{mg} \mathrm{kg}^{-1}$ & $\mathrm{~K} \mathrm{mg} \mathrm{kg}^{-1}$ \\
\hline Soil at 0 day & 6.5 & 80 & 0.238 & 0.0205 & 7.3 & 90 \\
\hline
\end{tabular}



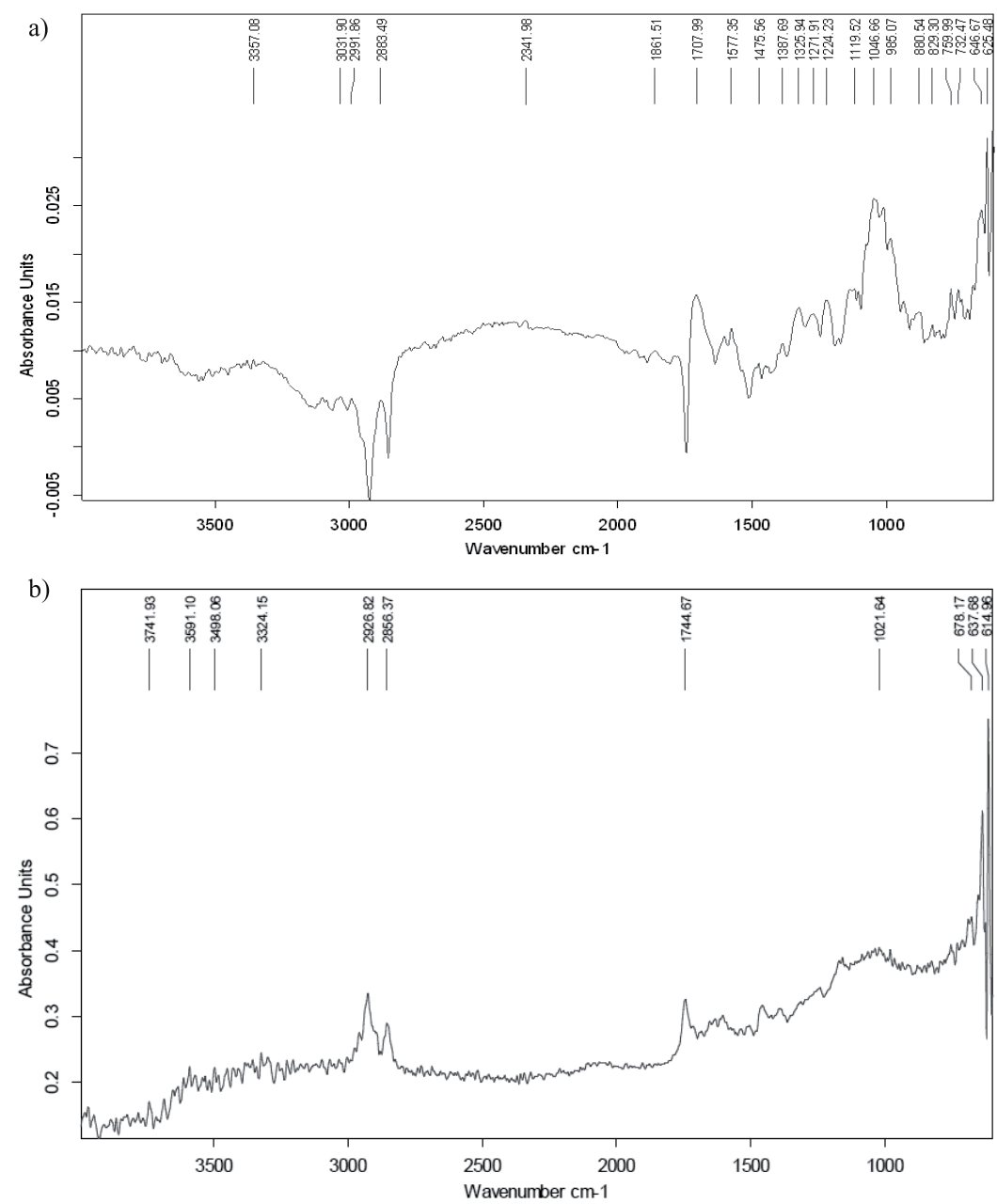

Fig. 3. a) FTIR analysis of fruit and vegetable waste biochar; b) FTIR analysis of nutshell biochar.

temperature, which caused breakage of weak bonds present in biochar structure leading to loss in hydrogen and oxygen content [20].

\section{Chemical Analysis of Nutshell Biochar by FTIR}

Analysis of nutshell biochar examined by FTIR showed that peak at $3741 / \mathrm{cm}$ was in correspondence to the double bonds vibrations of $\mathrm{C}$ and $\mathrm{N}$ atoms in benzene ring, whereas $3591 / \mathrm{cm}, 3498 / \mathrm{cm}$ and $3324 / \mathrm{cm}$ peaks corresponded to the O-H group vibrations. Peaks appear like those mentioned by Kazemipour et al. [21] and Köseoğlu [22]. The peaks at $2926 / \mathrm{cm}$ and $2856 / \mathrm{cm}$ represent the $\mathrm{C}-\mathrm{H}$ stretching vibration in the aromatic ring. Both $1744 / \mathrm{cm}$ and $1021 / \mathrm{cm}$ peaks indicated the $\mathrm{C}=\mathrm{C}$ stretching vibration and $\mathrm{CH}_{3}$ vibration, respectively, as observed by Yang et al. [23].

Table 3. Effect of biochar on physiochemical properties of soil.

\begin{tabular}{|c|c|c|c|c|c|c|c|}
\hline \multirow{2}{*}{$\begin{array}{l}\text { Soil physiochemical } \\
\text { parameters at time of } \\
\text { harvesting }\end{array}$} & \multirow[t]{2}{*}{ S0 control } & \multicolumn{2}{|c|}{$\begin{array}{c}\text { Fruit and vegetable waste } \\
\text { biochar }\end{array}$} & \multicolumn{2}{|c|}{ Nut shell biochar } & \multicolumn{2}{|c|}{$\begin{array}{c}\text { Mixture (fruit and vegetable } \\
\text { waste + nutshell biochar) }\end{array}$} \\
\hline & & S $0.5 \%$ & S $1 \%$ & S $0.5 \%$ & S 1\% & S $0.5 \%$ & $\mathrm{~S} 1 \%$ \\
\hline $\mathrm{pH}$ & 7.5 & 7.4 & 7.5 & 7.8 & 8 & 8.5 & 8.8 \\
\hline $\mathrm{EC} \mathrm{uS/cm}$ & 80 & 110 & 150 & 150 & 170 & 180 & 190 \\
\hline $\mathrm{TC} \%$ & 0.202 & 0.279 & 0.459 & 0.319 & 0.261 & 0.315 & 0.383 \\
\hline TN\% & 0.0205 & 0.0185 & 0.0305 & 0.0275 & 0.0225 & 0.0325 & 0.028 \\
\hline $\mathrm{P}$ mg kg-1 & 8 & 8.5 & 11 & 10.4 & 11.5 & 9.1 & 12 \\
\hline $\mathrm{K} \mathrm{mg} \mathrm{kg}^{-1}$ & 90 & 120 & 160 & 180 & 200 & 180 & 210 \\
\hline
\end{tabular}




\section{Biochar Effect on Soil Physiochemical Properties}

The initial physicochemical properties of soil samples at 0 day were also measured; soil had $\mathrm{pH}$ 6.5 , EC 80 us $/ \mathrm{cm}, 0.238 \%$ of total carbon, $0.0205 \%$ of total nitrogen, $7.3 \mathrm{mg} \mathrm{kg}^{-1}$ available phosphorus, and $90 \mathrm{mg} \mathrm{kg}^{-1}$ total potassium.

a)

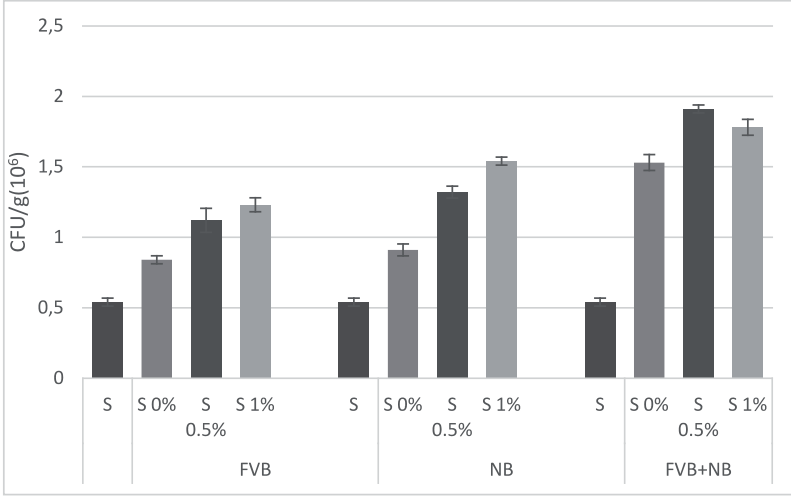

b)

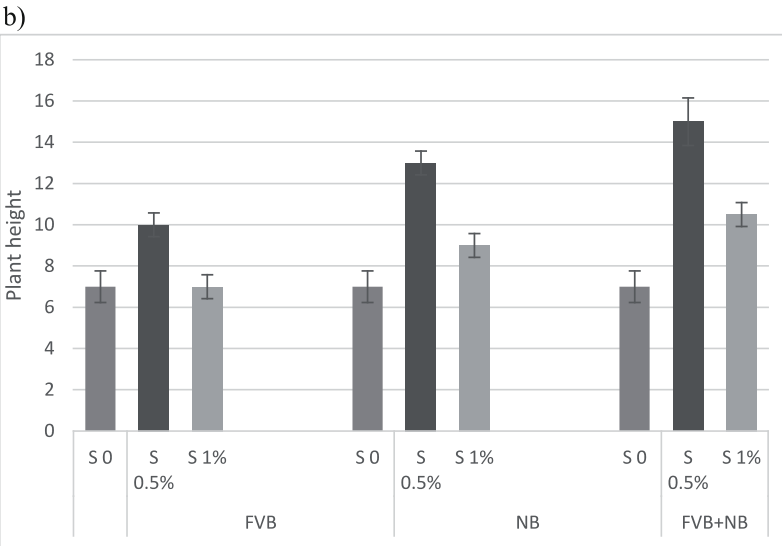

c)

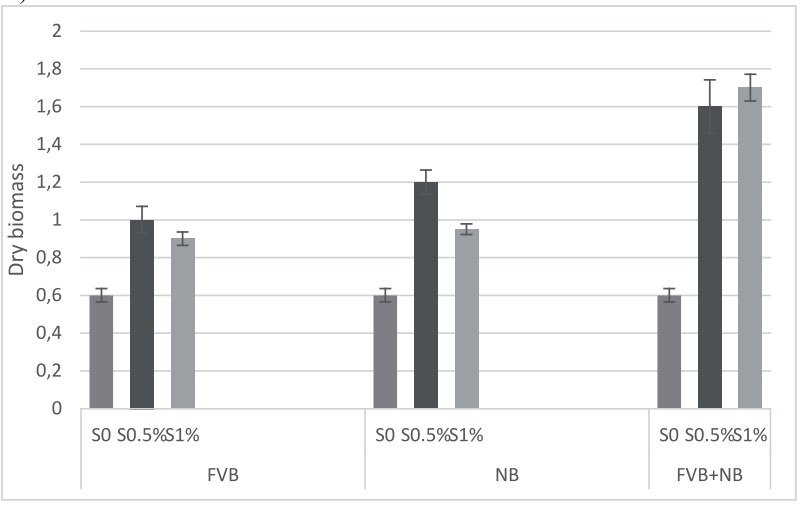

Fig. 4. a) effect of biochar $(\mathrm{FVB}=$ fruit and vegetable waste biochar, $\mathrm{NB}=$ nutshell biochar, $\mathrm{FVB}+\mathrm{NB}=$ mixture (fruit and vegetable waste +nutshell biochar)) on soil microbiology; b) Effect of biochar (FVB = fruit and vegetable waste biochar, $\mathrm{NB}=$ nutshell biochar, $\mathrm{FVB}+\mathrm{NB}=$ mixture (fruit and vegetable waste biochar +nutshell biochar)) on wheat height $(\mathrm{cm})$; c) Effect of biochar $(\mathrm{FVB}=$ fruit and vegetable waste biochar, $\mathrm{NB}=$ nutshell biochar, $\mathrm{FVB}+\mathrm{NB}=$ mixture (fruit and vegetable waste biochar + nutshell biochar)) on wheat dry biomass (g).
At the end of the study, results showed noticeable variations in the soil physicochemical properties by the addition of biochar. These changes are mainly attributed to nutrients present in biochar. It is possible that biochar incorporation into soil enhance soil physicochemical properties, decrease the bulk density, and improve the soil texture, water holding capacity and air circulation [6-24-25].

Soil $\mathrm{pH}$ is an important parameter that has a direct nexus with nutrient supply and salinity status of soil [26]. Highest $\mathrm{pH}$ of 8.8 was observed in soil amended with $1 \%$ mixture of biochar. It has been reported previously that in soil, biochar behaviour is liming, which increases soil $\mathrm{pH}$. [13]. Shifts in EC values rest on both the type of soil and biochar added. At $1 \%$ concentration of biochar mixture in soil the highest EC $190 \mathrm{us} / \mathrm{cm}$ was detected. The increase in the amount of biochar added caused an increase in soil EC values as also observed by Pandian et al. [11].

Another parameter is organic matter, which affects the soil physicochemical properties and microbial activities in the soil [27]. In 1\% Fruit and vegetable waste biochar the highest total carbon of $0.459 \%$ was recorded. As the amount of biochar increases, the carbon content also increases, which also helps in carbon storage in soil [10-28-29]. The highest total nitrogen of $0.0725 \%$ was examined in soil at $0.5 \%$ mixture of biochar. Our study explained that soil nitrogen directly depends on biochar concentration. As the amount of biochar increased it also increased the amount of nitrogen in soil. The lowest $0.0185 \%$ total nitrogen was reported in soil at $0.5 \%$ biochar (fruit and vegetable waste). Different factors like leaching, volatilization or erosion are also responsible for decreasing the nitrogen [30].

Phosphorous concentration was high in both nutshell biochar and the mixture of bio char at $1 \%$ concentration, i.e., 11.5 and $12 \mathrm{mg} / \mathrm{kg}$. Schmidt et al. [31] explained that the amount of phosphorous increased as the concentration of biochar increased. The lowest concentration of phosphorous $(8 \mathrm{mg} / \mathrm{kg})$ was reported in soil with no amendment of biochar. Potassium level was $210 \mathrm{mg} / \mathrm{kg}$ when examined in soil amended with $1 \%$ mixture of biochar. Potassium level was increased because a high amount of replaceable potassium was present in biochar [32].

\section{Biochar Effect on Soil Microbiology and Wheat Growth}

\section{Soil Microbiology}

CFU was counted for soil on the first day of the experiment and it was recorded as $0.5410^{6}$. As time passed, the bacterial population increased. After harvesting, the population of bacteria was $0.8410^{6}$, $1.1210^{6}$, and $1.2310^{6}$ at $0 \%, 0.5 \%$, and $1 \%$ fruit and vegetable waste biochar concentration respectively. In soil with nut shell biochar at $0 \%, 0.5 \%$, and $1 \%$ concentrations, bacterial count ranged from 0.91 and 
1.32 , to $1.5410^{6}$ respectively. In soil having a mixture of biochar at $0,0.5 \%$ and $1 \%$ concentrations, recorded CFU was $1.53,1.91$, and $1.7810^{6}$ respectively. Biochar may give suitable pore space for the colonisation of soil microbes. Biochar's micro pores protect soil microbes - particularly bacteria - from grazing because of the minor size $(0.15-1 \mu \mathrm{m})$, which could assume a vital role in enhancing the soil as a microbial habitat. The highest CFU of $1.9110^{6}$ was observed with $1 \%$ biochar mixture. Previous studies explained that adding biochar in soil caused an increase in microbial population due to the liming behaviour of biochar [33-34]. Previous studies reported that the amount of biochar increased beyond a certain limit, causing a reduction in the microbial population because the toxicity level increased in the soil [35].

\section{Wheat Growth}

The lengths of roots, shoots and leaves were measured to understand the effect of nutshell waste and fruit vegetable waste biochar on wheat growth. It is reported that biochar alteration in soil enhances the soil fertility and water retention capacity $[24,32$, 36]. Fruit and vegetable waste biochar and nut shell biochar both gave more or less similar results in terms of plant growth; nonetheless, best wheat growth was observed in soil when a $0.5 \%$ mixture of biochar (fruit and vegetable waste + nutshell) was added. Biochar is a nutrient-rich substrate that when applied in the soil aids plant growth [37-39]. As long as biomass is concerned, it was almost equal at $0.5 \%$ and $1 \%$ concentrations of biochar mixture. The shortest height of wheat crop was observed in control. Similarly, fruit and vegetable waste biochar at $1 \%$ concentration gave shorter height of wheat plant, suggesting that a higher concentration of biochar in soil can suppress wheat growth. In some studies we observed that if the biochar concentration increased it decreased plant development [40]. Other factors like environment, soil condition, water availability and land types also affect crop growth [41-42].

\section{Conclusions}

The current study suggests that the addition of biochar had a promising effect on plant growth as well as an impact on improving soil fertility. However, a mixture of both biochars showed enhanced impact on soil fertility and plant growth, which can be accredited to the synergistic effect of both types of biochar when applied in combination. Biochar had much influence on soil physiochemical parameters, which in turn effects plant growth. Biochar caused a significant increase in soil $\mathrm{pH}$ and electrical conductivity, enhanced soil microflora and gave good results at a concentration of $0.5 \%$. Above that concentration it suppressed the growth of wheat.

\section{Acknowledgments}

Funds for our study were provided by the Higher Education Commission, Islamabad, Pakistan under NRPU Pro-ject 6822

\section{Conflicts of Interest}

The authors declare no conflicts of interest.

\section{References}

1. MEMON M.H., KHAN K., ABBASS M.Y., KHAN G., KAMAL M.A. Impediments to Technology Adoption: A Case Study of Peach Production in District Swat, Pakistan. J. Man. Sci, 9 (2), 2015.

2. JUMA N.G. Interrelationships between soil structure/ texture, soil biota/soil organic matter and crop production. In Soil Structure/Soil Biota Interrelationships, 3, 1993.

3. BAUER A., BLACK A.L. Quantification of the effect of soil organic matter content on soil productivity. Am. J. Soil Sci. Soc, 58 (1), 185, 1994.

4. MAGDOFF F., VAN ES.H. Building soils for better crops. Sustainable Agriculture Network. Beltsville. 80, 2000.

5. BRUUN E.W., HAUGGAARD-NIELSEN H., IBRAHIM N., EGSGAARD H., AMBUS P., JENSEN P.A., DAMJOHANSEN K. Influence of fast pyrolysis temperature on biochar labile fraction and short-term carbon loss in a loamy soil. Biomass Bioenergy, 35 (3), 1182, 2011.

6. WARNOCK D.D., LEHMANN J., KUYPER T.W., RILLIG M.C. Mycorrhizal responses to biochar in soil - concepts and mechanisms. Plant Soil, 300 (1-2), 9, 2007.

7. LIANG B., LEHMANN J., SOLOMON D., KINYANGI J., GROSSMAN J., O'NEILL B., SKJEMSTAD J.O., THIES J., LUIZAO F.J., PETERSEN J., NEVES E.G. Black carbon increases cation exchange capacity in soils. Soil Sci. Soc. Am. J, 70 (5), 1719, 2006.

8. GROSSMAN J.M., O'NEILL B.E., TSAI S.M., LIANG B., NEVES E., LEHMANN J., THIES J.E. Amazonian anthrosols support similar microbial communities that differ distinctly from those extant in adjacent, unmodified soils of the same mineralogy. Microb Ecol, 60 (1), 192, 2010.

9. SAITO M., MARUMOTO T. Inoculation with arbuscular mycorrhizal fungi: the status quo in Japan and the future prospects. Plant Soil, 244, 273, 2002.

10. LEHMANN J., GAUNT J., RONDON M. Bio-char sequestration in terrestrial ecosystems - a review. Mitig. Adapt. Strateg. Glob. Chang, 11 (2), 403, 2006.

11. PANDIAN K., SUBRAMANIAYAN P., GNASEKARAN P., CHITRAPUTHIRAPILLAI S. Effect of biochar amendment on soil physical, chemical and biological properties and groundnut yield in rainfed Alfisol of semiarid tropics. Arch. Agron. Soil Sci, 62 (9), 1293, 2016.

12. SHAFIE S.T., SALLEH M.M., HANG L.L., RAHMAN M., GHANI W.A. Effect of pyrolysis temperature on the biochar nutrient and water retention capacity. Journal of Purity, Utility Reaction and Environment, 1 (6), 293, 2012.

13. BINTI AB AZIZ N.S., BIN MOHD NOR M.A., HAMZAH F. Suitability of biochar produced from 
biomass waste as soil amendment. Procedia Soc. Behav. Sci, 195, 2457, 2015.

14. PANSU M., GAUTHEYROU J. Handbook of soil analysis: mineralogical, organic and inorganic methods. Springer Science \& Business Media, 2007.

15. CARTER S., SHACKLEY S., SOHI S., SUY T.B., HAEFELE S. The impact of biochar application on soil properties and plant growth of pot grown lettuce (Lactuca sativa) and cabbage (Brassica chinensis). Agron, 3 (2), 404, 2013.

16. WU W., YANG M., FENG Q., MCGROUTHER K., WANG H., LU H., CHEN Y. Chemical characterization of rice straw-derived biochar for soil amendment. Biomass Bioenergy, 47, 268, 2012.

17. SHAABAN A., SE S.M., DIMIN M.F., JUOI J M., HUSIN M H., MITAN N.M. Influence of heating temperature and holding time on biochars derived from rubber wood sawdust via slow pyrolysis. J. Anal. Appl. Pyrolysis, 107, 31, 2014.

18. MOPOUNG S. Occurrence of carbon nanotube from banana peel activated carbon mixed with mineral oil. Int. J. Phys. Sci, 6 (7), 1789, 2011.

19. JINDO K., MIZUMOTO H., SAWADA Y., SANCHEZMONEDERO M.A., SONOKI T. Physical and chemical characterization of biochars derived from different agricultural residues. Biogeosciences, 11 (23), 6613, 2014.

20. DEMIRBAS A. Effects of temperature and particle size on bio-char yield from pyrolysis of agricultural residues. J. Anal. Appl. Pyrolysis, 72 (2), 243, 2004.

21. KAZEMIPOUR M., ANSARI M., TAJROBEHKAR S., MAJDZADEH M., KERMANI H.R. Removal of lead, cadmium, zinc, and copper from industrial wastewater by carbon developed from walnut, hazelnut, almond, pistachio shell, and apricot stone. J. Hazard. Mater, 150 (2), 322, 2008

22. KÖSEOĞLU E., AKMIL-BAŞAR C. Preparation, structural evaluation and adsorptive properties of activated carbon from agricultural waste biomass. Adv. Powder Technol, 26 (3), 811, 2015.

23. YANG J., QIU K. Preparation of activated carbons from walnut shells via vacuum chemical activation and their application for methylene blue removal. Chem. Eng. J, 165 (1), 209, 2010

24. OGAWA M., OKIMORI Y. Pioneering works in biochar research, Japan. Soil Res, 48 (7), 489, 2010.

25. STEINER C., GLASER B., GERALDES TEIXEIRA W., LEHMANN J., BLUM W E., ZECH W. Nitrogen retention and plant uptake on a highly weathered central Amazonian Ferralsol amended with compost and charcoal. J. Plant Nutr. Soil Sci, 171 (6), 893, 2008.

26. PIETIKÄINEN J., KIIKKILÄ O., FRITZE H. Charcoal as a habitat for microbes and its effect on the microbial community of the underlying humus. Oikos, 89 (2), 231, 2000.

27. EKWUE E.I. Organic-matter effects on soil strength properties. Soil and Tillage Res, 16 (3), 289, 1990.

28. DEMISIE W., LIU Z., ZHANG M. Effect of biochar on carbon fractions and enzyme activity of red soil. Catena, 121, 214, 2014
29. ZEE T.E., NELSON N.O., NEWDIGGER G. Biochar and Nitrogen Effects on Winter Wheat Growth. Kansas Agricultural Experiment Station Research Reports, 3 (3), $6,2017$.

30. STREUBEL J.D., COLLINS H.P., GARCIA-PEREZ M., TARARA J., GRANATSTEIN D., KRUGER C.E. Influence of contrasting biochar types on five soils at increasing rates of application. Soil Sci. Soc. Am. J, 75 (4), 1402, 2011.

31. SCHMIDT M.W., NOACK A.G. Black carbon in soils and sediments: analysis, distribution, implications, and current challenges. Global Biogeochem Cycles, 14 (3), 777, 2000.

32. CHAN K Y., VAN ZWIETEN L., MESZAROS I., DOWNIE A., JOSEPH S. Agronomic values of greenwaste biochar as a soil amendment. Soil Res, 45 (8), 629, 2008.

33. DEENIK J.L., MCCLELLAN T., UEHARA G., ANTAL M.J., CAMPBELL S. Charcoal volatile matter content influences plant growth and soil nitrogen transformations. Soil Sci. Soc. Am. J, 74 (4), 1259, 2010.

34. AMELOOT N., DE NEVE S., JEGAJEEVAGAN K., YILDIZ G., BUCHAN D., FUNKUIN Y.N., PRINS W., BOUCKAERT L., SLEUTEL S. Short-term $\mathrm{CO}_{2}$ and $\mathrm{N}_{2} \mathrm{O}$ emissions and microbial properties of biochar amended sandy loam soils. Soil Biology and Biochemistry, 57, 401, 2013.

35. DEMPSTER D.N., JONES D.L., MURPHY D.V. Organic nitrogen mineralisation in two contrasting agroecosystems is unchanged by biochar addition. Soil Biol. and Biochem, 48, 47, 2012.

36. MARRIS E. Putting the carbon back: Black is the new green. Nature, 624, 2006.

37. GASKIN J.W., STEINER C., HARRIS K., DAS K.C., BIBENS B. Effect of low-temperature pyrolysis conditions on biochar for agricultural use. Transactions of the ASABE, 51 (6), 2061, 2008.

38. SALIM B.B.M. Influence of biochar and seaweed extract applications on growth, yield and mineral composition of wheat (Triticum aestivum L.) under sandy soil conditions. Ann. Agric. Sci, 61 (2), 257, 2016.

39. SOHI S P., KRULL E., LOPEZ-CAPEL E., BOL R. A review of biochar and its use and function in soil. Adv. Agron, 105, 47, 2010.

40. LUO X., LIU G., XIA Y., CHEN L., JIANG Z., ZHENG H., WANG Z. Use of biochar-compost to improve properties and productivity of the degraded coastal soil in the Yellow River Delta, China. J. Soil Sediment, 17 (3), 780, 2017.

41. VAN ZWIETEN L., KIMBER S., MORRIS S., CHAN K.Y., DOWNIE A., RUST J., JOSEPH S., COWIE A. Effects of biochar from slow pyrolysis of papermill waste on agronomic performance and soil fertility. Plant Soil, 327 (1-2), 235, 2010.

42. HAEFELE S.M., KONBOON Y., WONGBOON W., AMARANTE S., MAARIFAT A.A., PFEIFFER E.M., KNOBLAUCH C. Effects and fate of biochar from rice residues in rice-based systems. Field Crops Res, 121 (3), 430, 2011. 